Received: 15-06-2021

(Date-Month-Year)
Revised: 29-10-2021

(Date-Month-Year)
Published: 30-10-2021

(Date-Month-Year)

\title{
EFEKTIVITAS PEMBELAJARAN MATEMATIKA BERBASIS DARING (E- LEARNING) TERHADAP KEPERCAYAAN DIRI SISWA KELAS V SDI Al-HUSNA
}

\author{
Intan Safira Dwi Santy ${ }^{1}$, Heni Pujiastuti ${ }^{2}$ \\ ${ }^{1,2}$ FKIP/Pendidikan Matematika, Universitas Sultan Ageng Tirtayasa, Indonesia \\ ${ }^{1} 2225180067 @$ untirta.ac.id \\ ${ }^{2}$ henipudjiastuti@untirta.ac.id
}

\begin{abstract}
Abstrak: Penelitian ini bertujuan untuk mengetahui efektivitas pembelajaran matematika berbasis daring (e-learning) terhadap kepercayaan diri siswa di SDI Al-Husna. Pada masa kini, proses pembelajaran dengan menggunakan E-learning dapat bersifat interaktif sehingga siswa mampu berinteraksi dengan teknologi sebagai media belajarnya. Dikarenakan banyaknya pengaruh luar yang tidak diawasi oleh guru sehingga ketidakfokusan siswa berkurang terhadap materi yang disampaikan, akibatnya siswa tidak menyimak dengan baik, siswa tersebut tertinggal dan enggan untuk bertanya kembali, sehingga rasa kepercayaan diri siswa berkurang, baik untuk bertanya maupun berpendapat. Kurangnya kepercayaan diri siswa terhadap dirinya sendiri dapat berpengaruh terhadap pola berpikirnya, sehingga sering menutup diri. Masalah kepercayaan diri pada individu menjadi prioritas yang harus dibangun untuk mengefektifkan pembelajaran berbasis e-learning. Metode pengumpulan data yang diambil adalah dengan memberikan angket kepada siswa.
\end{abstract}

Katakunci: Pembelajaran Matematika; E-Learning; Kepercayaan Diri.

\begin{abstract}
This research aims to determine the effectiveness of mathematics learning (elearning) on student's self-confidence at SDI Al-Husna. The learning process using E-learning can be interactive so that students can interact with technology as a learning. Many external influences that aren't supported by the teacher so student unfocusedness is reduced to the material presented, as a result students don't listen well, these students are left behind and are reluctant to ask again, so that student self-confidence decreases, both to ask and giving opinion. Student lack of confidence in themselves can affect their thinking patterns, they often close themselves off. The problem of self-confidence in individuals must be built to make E-learning effective. The method is taken by giving a questionnaire to students.
\end{abstract}

Keywords: Mathematics Learning; E-Learning; Self-Confidence.

\section{Pendahuluan}

Pada masa pandemi Covid-19, siswa melakukan pembelajaran secara dalam jaringan (daring) dengan menggunakan platform e-learning yang sangat berguna bagi siswa dalam menerima materi yang diberikan secara efektif dan efisien. Dengan adanya $e$ learning membuat siswa lebih mudah dalam menerima informasi dengan memanfaatkan teknologi yang ada, dengan menggunkan media visual dan audio visual membantu siswa dalam memahami konsep matematika. Pembelajaran dengan menggunakan $e$ learning yang tepat akan berdampak positif terhadap hasil belajar siswa. Guru sebagai fasilitator artinya guru harus 
berperan memberikan pelayanan untuk memudahkan siswa dalam kegiatan proses pembelajaran, peran guru menjadi sangat penting dikarenakan pembeajaran yang berubah secara daring, guru harus lebih memilih platform e-learning apa yang mudah dipahami oleh siswa, beberapa guru ada yang memberi materi melalui rangkuman tulisan, ada juga yang memberikan video pembelajaran, dan ada juga yang melalukan webmeeting untuk menjelaskan materi, namun seringkali siswa menjadi pasif dikarenakan kurangnya interaksi antara guru dan siswa yang menyebabkan kurangnya pemahaman terhadap materi yang telah disampaikan baik secara langsung ataupun tidak langsung.

Dalam proses pembelajaran dengan menggunakan e-learning, seringkali terjadi interaksi satu arah, misalnya guru hanya menyediakan ruang diskusi untuk siswa dapat bertanya serta berpendapat secara bebas, untuk pertemuan pertama bisa saja kepercayaan diri siswa akan meningkat sehingga aktif didalam ruang tersebut, namun dipertemuan-pertemuan selanjutnya apakah siswa tidak akan merasa bosan dengan sistem pembelajaran yang seperti itu, sehingga siswa yang memiliki tingkat kompetitifnya serta kepercayaan diri lebih tinggi akan lebih sering bertanya, sedangkan siswa yang lainnya lebih cenderung pasif. Sama halnya juga dengan memanfaatkan e-learning dengan menggunakan webmeeting/video conference, sering terjadi interaksi satu arah dimana hanya guru yang berbicara, terdapat faktor yang memengaruhinya, salah satunya dikarenakan pemahaman siswa yang kurang sehingga membuat kepercayaan diri siswa dalam bertanya dan berpendapat menurun. Guru ingin membentuk karakter siswa yang aktif dimana pastinya guru akan meningkatkan kepercayaan diri siswa, namun hal ini terkadang belum dapat dicapai oleh guru ketika sedang melakukan pembelajaran di ruang kelas, peran guru menjadi lebih sangat penting dikarenakan harus memikirkan bagaimana meningkatkan keaktifan dan rasa percaya diri siswa pada saat pembelajaran daring. Ketika tidak memahami materi, beberapa siswa ada yang cenderung menghindar, menutup diri, kurang inisiatif, takut untuk terlihat di depan orang banyak dikarenakan kurangnya rasa percaya diri siswa sehingga dapat menghambat pemahaman siswa terhadap proses pembelajaran.

Perkembangan teknologi dan informasi memiliki pengaruh yang sangat besar terhadap proses pengajaran dan pembelajaran. Teknologi juga dapat meningkatkan kualitas pendidikan baik di negara maju maupun di negara yang sedang berkembang, khususnya Indonesia. Proses pengajaran dan pembelajaran sangatlah bergantung kepada teknologi, salah satunya dengan menggunakan platform E-learning yang dikenal mampu untuk mengatasi masalah pendidikan. Seperti yang telah disampaikan oleh Keengwe \& Georgina dalam penelitiannya telah menyatakan bahwa perkembangan teknologi memberikan perubahan terhadap pelaksanaan pengajaran dan pembelajaran (Keengwe \& Georgina, 2012). E-learning pertama kali dimulai oleh Universitas Illinois, UrbanaChampaign pada tahun 1960 dengan menggunakan Sistem Instruksi Berbasis Komputer (Computer-Assisted Instruction) yang dijalankan di komputer PLATO, diciptakan oleh Profesor Don Bitzer. Sejak tahun 1990, era CBT (Computer-Based Trainging) atau Pelatihan Berbasis Komputer mulai berkembang. Isi materinya dapat berupa tulisan maupun multimedia (foto, ilustrasi, audio, animasi, dan video). 
Teknologi informasi dapat diterima sebagai media dalam melakukan proses pendidikan, termasuk membantu proses belajar mengajar, yang juga melibatkan pencarian referensi dan sumber informasi (Wekke \& Hamid, 2013).

Efektivitas dari penggunaan $E$ learning dipengaruhi banyak hal. Kemampuan adaptasi dan adopsi yang baik sangat menentukan efektivitas $E$ learning (Wannemacher, 2006). Berkaitan dengan efektivitas e-learning, faktor penerimaan seseorang terhadap sistem informasi dan komunikasi baru juga menjadi penting. Kesiapan siswa serta pemahaman dan tingkat kepercayaan diri siswa dalam menggunakan e-learning menjadi faktor yang paling utama dalam menentukan efektivitas e-learning. Banyak sekali platform E-learning yang dapat diakses baik oleh dosen maupun mahasiswa. Edmodo, Modle, Google Classroommerupakan contoh platform $e$ learningyang menyediakan fasilitas LMS (Learning Management System). LMS merupakan sistem yang menyediakan kelas berbasis tekno-logi informasi dan komunikasi yang dapat diisi oleh dosen dengan materi, tugas, sumber belajar dan lain-lain(Shawar \& Al-Sadi, 2010). Sistem ini juga mempermudahkan komunikasi antar dosen dengan mahasiswa. Untuk melakukan video conference, dapat juga menggunakan aplikasi Zoom Meeting, Google Meet, Skype dan sebagainya.

Pada masa kini, proses pembelajaran dengan menggunakan $E$ learning dapat bersifat interaktif sehingga siswa mampu berinteraksi dengan teknologi sebagai media belajarnya. Pada pembelajaran matematika, platform $E$ learning sangat membantu siswa dalam menerima informasi yang diberikan oleh tenaga pendidik, dapat menggunakan berbagai macam aplikasi yang sudah tersedia dengan fitur yang sangat membantu pada saat proses pengajaran dan pembelajaran. Dikarenakan banyaknya pengaruh luar yang tidak diawasi oleh guru sehingga sering terjadi ketidakfokusan siswa terhadap materi yang disampaikan, akibatnya siswa tidak menyimak dengan baik dan ketika telah menyimak kembali, siswa tersebut tertinggal dan enggan untuk bertanya kembali, sehingga rasa kepercayaan diri siswa berkurang, baik dalam bertanya maupun berpendapat. Kurangnya kepercayaan diri siswa terhadap dirinya sendiri dapat berpengaruh terhadap pola berpikirnya. Siswa yang tidak percaya diri kurang percaya pada kemampuannya sehingga sering menutup diri. Masalah kepercayaan diri pada individu menjadi prioritas yang harus dibangun untuk mengefektifkan pembelajaran berbasis $e$ learning.

\section{Metode Penelitian}

Penelitian ini dilaksanakan pada bulan 9 Juni 2021. Populasi yang digunakan dalam penelitian ini adalah siswa/i kelas $\mathrm{V}$ di SDI Al-Husna berjumlah 26 siswa. Pengambilan sampel dalam penelitian ini menggunakan metode simple random sampling (pengambilan anggota sampel dari populasi yang dilakukan secara acak tanpa memperhatikan strata dalam populasi itu). Dengan menggunakan metode tersebut didapat sampel 15 responden.

Dalam penelitian ini, metode yang digunakan adalah metode survey dengan pendekatan kuantitatif. Metode survey dipilih karena penulis ingin mendapatkan sumber informasi dari responden mengenai objek terterntu dengan menggunkan angket skala likert. Skala kepercayaan diri ini terdiri dari pernyataan positif (favorable) dan pernyataan negatif (unfavorable), dimana

Pi: Mathematics Education Journal 
setiap pernyataan memiliki lima pilihan jawaban. Skala likert yang digunakan dalam survey ini berbentuk skala ordinal dengan 5 pilihan: (5) sangat setuju, (4) setuju, (3) ragu-ragu, (2) tidak setuju, (1) sangat tidak setuju.

Pengumpulan data yang digunakan untuk mengetahui pengaruh kepercayaan diri siswa yaitu menggunakan angket dengan skala kepercayaan diri. Skala ini berbentuk angket yang memuat sejumlah pernyataan yang digunakan untuk memperoleh informasi dari sejumlah responden dalam arti laporan tentang pribadinya dan halhal yang ia diketahui (Arikunto, 2013).

Pengolahan data hasil diawali dengan menetapkan bobot nilai rata-rata tertimbang untuk masing-masing pertanyaan. Rumus yang digunakan adalah sebagai berikut:

\section{Bobot nilai rata-rata tertimbang $=$} jumlah bobot / jumlah unsur

Selanjutnya, untuk mengetahui nilai rata-rata unit pertanyaan digunakan pendekatan rata-rata tertimbang dengan rumus sebagai berikut :

RSV $=$
(Total dari nilai persepsi tiap unsur /
Total unsur yang terisi) x Nilai
Penimbang

Untuk memudahkan interpretasi terhadap hasil yaitu 25 sampai dengan 100, RSV kemudian dikonversikan ke dalam 100, dengan rumus :

$$
\mathrm{KSV}=\mathrm{RSV} \times 25
$$

Interpretasi hasil perhitungan ini selanjutnya dapat dilihat berdasarkan tabel berikut.

Table 1. Interprestasi Hasil

\begin{tabular}{ccccc}
\hline $\begin{array}{c}\text { Nilai } \\
\text { Persepsi }\end{array}$ & $\begin{array}{c}\text { Nilai } \\
\text { Interval }\end{array}$ & $\begin{array}{c}\text { Konversi } \\
\text { Nilai } \\
\text { Interval }\end{array}$ & $\begin{array}{c}\text { Mutu } \\
\text { Pelayanan }\end{array}$ & Persepsi \\
\hline 1 & $1,00-$ & $25,00-$ & $\mathrm{D}$ & $\begin{array}{c}\text { Sangat } \\
\text { Buruk }\end{array}$ \\
& 2,59 & 64,99 & & Buruk \\
2 & $2,60-$ & $65,00-$ & $\mathrm{C}$ & Sangat Baik \\
& 3,06 & 76,60 & & \\
3 & $3,07-$ & $76,61-$ & $\mathrm{B}$ & Baik \\
& 3,53 & 88,30 & & \\
4 & $3,59-$ & $88,31-$ & A &
\end{tabular}

\section{Hasil dan Pembahasan}

Berdasarkan perhitungan survey, jumlah nilai dari setiap unsur pertanyaan diperoleh dari jumlah rata-rata setiap unsur pertanyaan. Adapun survey komposit (gabungan) untuk setiap unsur pertanyaan dikalikan dengan penimbang yang sama, yaitu 0,067 .

Bobot nilai rata-rata tertimbang

$=$ Jumlah bobot $/$ jumlah unsur

$=1 / 15$

$=0,067$

Hasil nilai rata-rata unsur dan masing-masing unsur pertanyaan adalah sebagai berikut:

Table 2. Nilai Rata-Rata Pertanyaan

\begin{tabular}{cc}
\hline $\begin{array}{c}\text { Nilai } \\
\text { Persepsi }\end{array}$ & Nilai Interval \\
\hline 1 & 1,4 \\
2 & 2,8 \\
3 & 3,6 \\
4 & 3,6 \\
5 & 3,067 \\
6 & 3,6 \\
7 & 3,73 \\
8 & 3,267 \\
9 & 2,467 \\
10 & 3,93 \\
11 & 2,53 \\
12 & 3,53 \\
13 & 3,6 \\
14 & 2,6 \\
15 & 1,73 \\
\hline
\end{tabular}

Maka untuk mengetahui nilai survey unit pelayanan dihitung dengan cara masing-masing nilai unsur 
pertanyaan dikalikan dengan nilai penimbang yaitu sebagai berikut:

$\mathrm{RSV}=3,046267$

Dengan demikian, nilai survey
unsur pernyataan hasilnya dapat
disimpulkan sebagai berikut:

$\mathrm{KSV}=\mathrm{RSV} \times 25$

$\mathrm{KSV}=3,046267 \times 25$

$\mathrm{KSV}=76,15667$

Mutu Pelayanan : C

Persepsi Kinerja : Buruk

Pengolahan data dan penghitungan indeks dilakukan dengan program komputer yaitu menggunakan aplikasi Microsoft Excel.

\section{Simpulan}

Berdasarkan hasil survey terhadap 15 responden dari total poupulasi 26 siswa, serta terdapat 15 pertanyaan serta 3 essai. Hal ini dapat dilihat dari nilai survey unit pelayanan (RSV) berdasarkan nilai rata-rata pertanyaan yaitu sebesar 3,046267. Kemudian, nilai survey unsur (KSV) yaitu 76,15667. Berdasarkan Tabel 1. Interprestasi Hasil Survey menunjukkan bahwa nilai tersebut masuk kedalam Konversi Nilai Interval 65,00 sampai dengan 76,60 dimana terdapat pada Nilai Interval antara 2,60 dan 3,06 dimana interval tersebut menunjukkan mutu pelayanan dari sebuah penelitian yang sudah dibahas menujukkan $\mathrm{C}$ atau dapat disimpulkan persepsi kinerja pembelajaran matematika berbasis daring (E-learning) terhadap kepercayaan diri siswa kelas V Sekolah Dasar Islam AlHusna dinilai buruk.

\section{Ucapan Terimakasih}

Puji syukur penulis haturkan kehadirat Tuhan Yang Maha Esa, atas rahmat, karunia, taufik, serta hidayahnya, Penulis dapat menyelesaikan artikel yang berjudul "Efektivitas Pembelajaran Matematika Berbasis Daring (E-learning) Terhadap Kepercayaan Diri Siswa Kelas V SDI Al-Husna".

Dalam kesempatan ini, Penulis juga berterima kasih kepada seluruh pihak yang terlah berkontribusi dalam penyusunan artikel ini. Mulai dari Kepala Sekolah SDI Al-Husna, Guru-guru SDI Al-Husna, siswa kelas $\mathrm{V}$ yang telah bersedia untuk mengisi angket/kuesioner yang telah saya berikan, serta rekan-rekan saya yang lain yang telah membantu memberikan masukan, saran, serta motivasi baik materi maupun pikirannya sehingga Penulis dapat menyelesaikan artikel ini. Penulis berharap artikel ini dapat berguna dan bermanfaat bagi para pembaca untuk menambah wawasan serta pengetahuan tentang keefektifan pembelajaran berbasis daring terhadap kepercayaan diri siswa.

\section{Daftar Pustaka}

Setiaji, B., \& Dinata, P. A. C. (2020). Analisis kesiapan mahasiswa jurusan pendidikan fisika menggunakan E-learning dalam situasi pandemi Covid-19. Jurnal Inovasi Pendidikan IPA, 6(1), 5970.

Subekti, I., Sukestiyarno, Y. L., \& Waluya, S. B. (2012). Efektivitas Penerapan Pembelajaran Matematika Berbasis E-learning dalam Kerangka Laboratorium Teenzania Materi Trigonometri Kelas X. Innovative Journal of Curriculum and Educational Technology, 1(2).

Ayus, A. D., Gusniwati, G., \& Buhaerah, B. (2021). Efektivitas Pembelajaran Matematika Berbasis Daring (ELearning) Terhadap Prestasi Belajar

Pi: Mathematics Education Journal 
Siswa. Pi: Mathematics Education Journal, 4(1), 31-36.

Sari, J., \& Hayati, F. (2019). Analisis Kemampuan Pemahaman Konsep Matematis Siswa Smp Pada Materi Kubus Dan Balok. Pi: Mathematics Education Journal, 2(1), 14-25.

Hakim, L., \& Khusniya, I. L. (2019). Efektifitas Pembelajaran Berbasis Daring: Sebuah Bukti Pada Pembelajaran Bahasa Inggris. Universitas Islam Negeri Mataram: Jurnal Tatsqif. 